
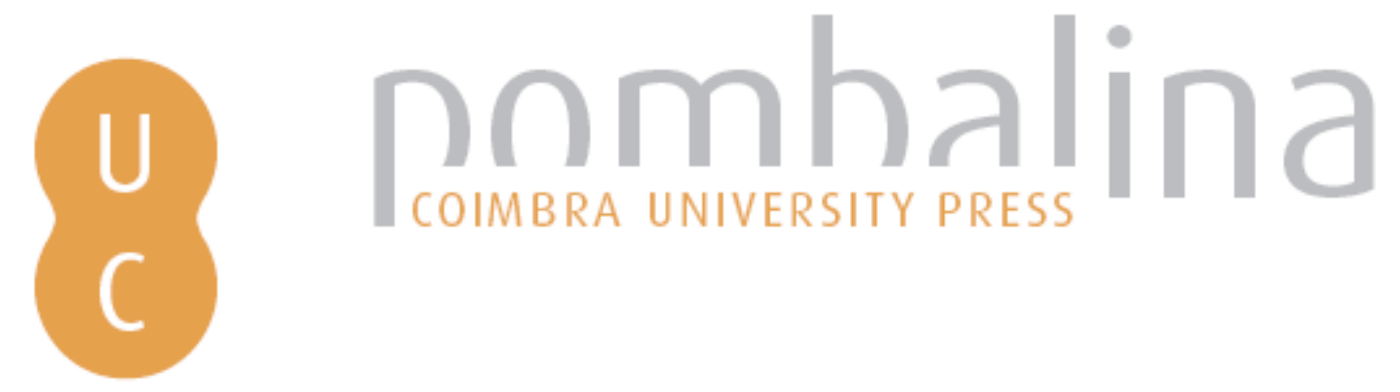

\title{
Assessing the distribution and use of income and changes in income with social accounting matrices
}

\author{
Autor(es): $\quad$ Santos, Susana \\ Publicado por: Imprensa da Universidade de Coimbra \\ URL \\ persistente: URI:http://hdl.handle.net/10316.2/38160 \\ DOI: $\quad$ DOI:http://dx.doi.org/10.14195/978-989-26-1039-9_14 \\ Accessed : $\quad$ 26-Apr-2023 08:17:44
}

A navegação consulta e descarregamento dos títulos inseridos nas Bibliotecas Digitais UC Digitalis, UC Pombalina e UC Impactum, pressupõem a aceitação plena e sem reservas dos Termos e Condições de Uso destas Bibliotecas Digitais, disponíveis em https://digitalis.uc.pt/pt-pt/termos.

Conforme exposto nos referidos Termos e Condições de Uso, o descarregamento de títulos de acesso restrito requer uma licença válida de autorização devendo o utilizador aceder ao(s) documento(s) a partir de um endereço de IP da instituição detentora da supramencionada licença.

Ao utilizador é apenas permitido o descarregamento para uso pessoal, pelo que o emprego do(s) título(s) descarregado(s) para outro fim, designadamente comercial, carece de autorização do respetivo autor ou editor da obra.

Na medida em que todas as obras da UC Digitalis se encontram protegidas pelo Código do Direito de Autor e Direitos Conexos e demais legislação aplicável, toda a cópia, parcial ou total, deste documento, nos casos em que é legalmente admitida, deverá conter ou fazer-se acompanhar por este aviso.

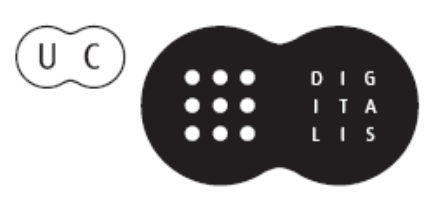


IMPRENSA DA UNIVERSIDADE DE COIMBRA

COIMBRA UNIVERSITY PRESS

\section{ASSESSMENT \\ METHODOLOGIES}

ENERGY, MOBILITY AND OTHER

REAL WORLD APPLICATION

\section{PEDRO GODINHO \\ JOANA DIAS}

EDITORS

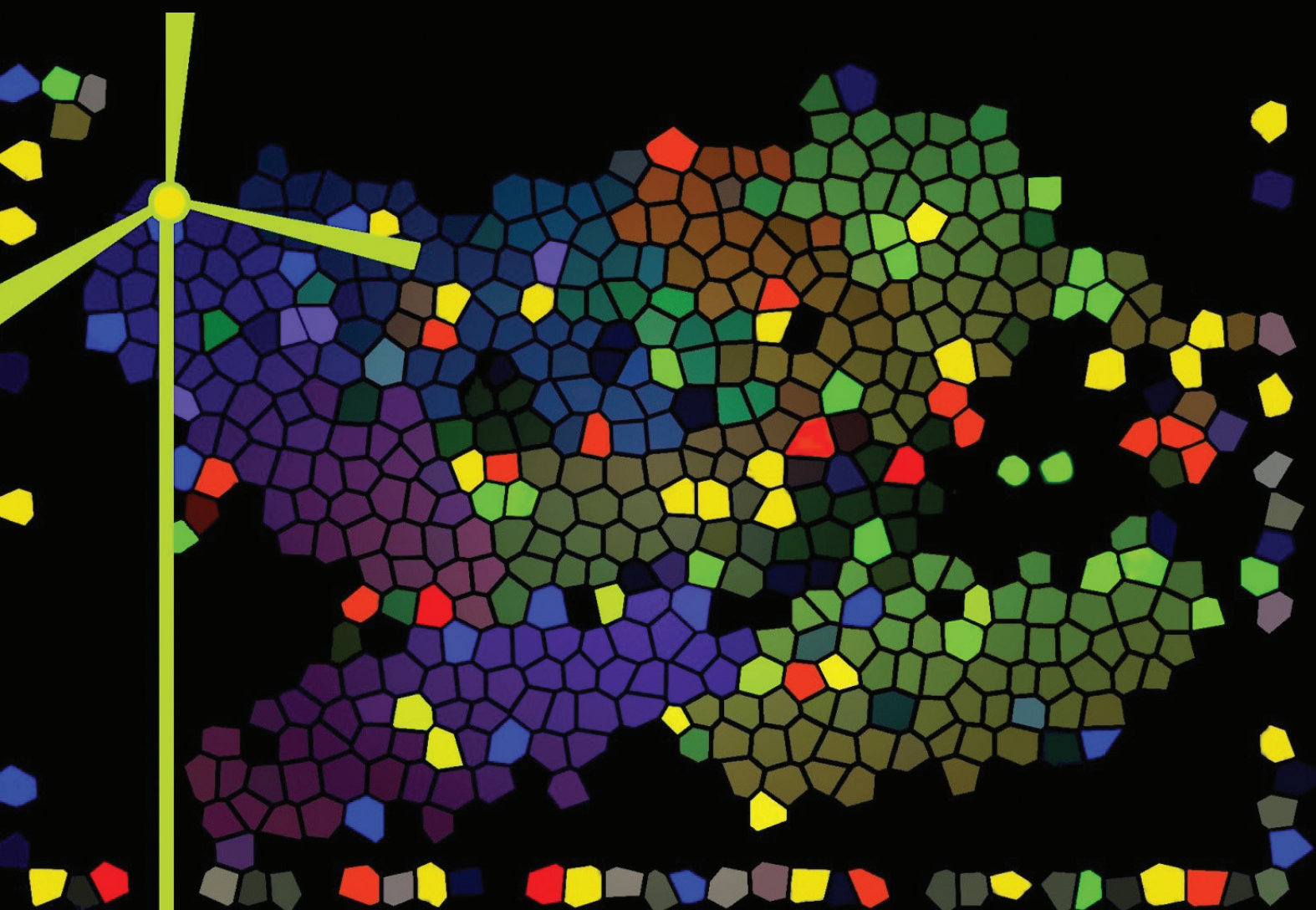




\title{
ASSESSING THE DISTRIBUTION AND USE OF INCOME AND CHANGES IN INCOME WiTh SOCIAL ACCOUNTING MATRICES
}

\author{
Susana Santos 1
}

\begin{abstract}
Several different areas of the socio-economic activity of countries, and in particular the distribution of income, can be studied with the use of Social Accounting Matrices (SAMs).

The features underlying a SAM allow for the reading and interpretation of the socio-economic activity of countries, leading to the production of an empirical work that can highlight specific aspects of the reality under study and offers the chance to perform experiments with changes in those aspects. Thus, SAMs can also be used to support policy decision processes.

With the aid of some methodological principles based on the works of R. Stone, G. Pyatt and J. Round, a SAM-based approach to the study of income distribution is carried out, seeking to provide both an empirical and a theoretical description of the socio-economic activity of a country, respectively through a numerical and an algebraic version of a SAM. The algebraic version can also be referred to as a 'SAM-based model'.
\end{abstract}

This study uses the nomenclatures of the latest version of the System of National Accounts (2008 SNA).

By including production and institutions accounts in a matrix format, the structural features of a country's production and income distribution can be worked upon together, making it possible to capture specific networks of linkages and the corresponding multiplier effects, in subsequent modelling exercises.

\footnotetext{
${ }^{1}$ ISEG - Lisbon School of Economics and Management, Universidade de Lisboa UECE (Research Unit on Complexity and Economics) and DE (Department of Economics) E-mail: ssantos@iseg.ulisboa.pt
} 
A basic SAM is presented, with rows and columns representing accounts. The production accounts are represented by activities (or industries), products (or goods and services), and factors of production. The (domestic) institutions are represented by the current, capital and financial accounts. The rest of the world account represents the "external" part of the (domestic) economy.

Bearing in mind the importance of ensuring the consistency of the whole system, possible disaggregations and extensions to that basic structure are analysed.

Aggregates and balancing items that can be identified and calculated outside this matrix format are also presented.

An assessment of a country's distribution and use of income is presented, by means of the identification of some of the underlying structural features of SAMs.

Macroeconomic effects of changes in income are then identified by way of an experiment with a change in the taxes on income and wealth, paid by the households to the government, using a SAM-based approach.

The exposition is accompanied by an example which is applied to Portugal.

Keywords: Social Accounting Matrix; National Accounts; Income Distribution; Macroeconomic Modelling.

\section{Introduction}

The Social Accounting Matrix (SAM) is a tool that has specific features that can be used to study the socio-economic activity of countries. Such features allow for the reading and interpretation of the reality under study, leading to the production of an empirical work, which not only highlight specific aspects of that activity, but also offers the chance to perform experiments with different interventions with regard to its functioning.

Section 2 outlines how the SAMs can be used to measure and model the socio-economic activity of countries, and also how they can be used as an alternative support for studies being carried out in several areas, as well as for supporting those taking part in the policy decision process. The main features of the SAM-based approach are outlined in Subsection 2.1 , by adopting a methodological framework based on Richard 
Stone's research and that of his followers, according to which the SAM can describe the activity of countries, either empirically or theoretically, depending respectively on whether it is presented in a numerical or an algebraic version. In Subsection 2.2, a proposal is presented for the development of a basic SAM, together with an explanation of possible alternative taxonomies. In Subsection 2.3, the accounting multipliers are presented as a possible algebraic version of a SAM, to be used in a SAM-based approach.

In Sections 3 and 4, an assessment is made of the distribution and use of income, and also of macroeconomic effects of changes in income, respectively. In the former case, some of the structural features underlying the SAMs are identified, and, in the latter, an experiment based on a change in the taxes on income and wealth, paid by the households to the government, is performed using a SAM-based approach.

Finally, Section 5 summarises and presents some concluding remarks on how SAMs can be useful working tools for assessing the distribution and use of income, as well as, for the analysis of possible macroeconomic effects of changes in a country's income.

Throughout the research, the methodologies are accompanied by an application for Portugal.

\section{Measuring and modelling the socio-economic activity of coun- tries with SAMs}

\subsection{The SAM and the SAM-based approach}

The Social Accounting Matrix (SAM) is a square matrix which measures and models the socio-economic activity of a country, depending respectively on whether it is in a numerical or in an algebraic version. In this way, specific aspects of that activity can be studied through a SAM-based approach, thus benefitting from a greater analytical content which is provided by the matrix format, and allowing for the capture of networks of linkages that have not been captured otherwise. 
A numerical version of a SAM can be seen as an empirical snapshot of the socio-economic activity of a country, in which each cell has a specific value, with the sums of rows being equal to the sums of the columns.

A theoretical snapshot of the socio-economic activity of a country can be given by an algebraic version of a SAM, in which each cell is filled with one or more algebraic expressions which, together with those of all the other cells, form a SAM-based model, the calibration of which involves the replication of a numerical version.

Therefore, the SAM is a working tool which, on one hand, enables the reading of the reality under study and, on the other hand, offers a chance to simulate different interventions with regard to its functioning.

With a methodological framework based on the works of R. Stone, G. Pyatt and J. Round the proposal is to work SAMs with production and institutional accounts, to represent the transactions within the domestic economy, and one or more rest of the world accounts, to represent the transactions between the economy and abroad.

The level of detail of the versions of SAMs used will depend on the purposes of the study in which it can be used as a working tool, as well as the available data.

The National Accounts are the main reference source of data on the socio-economic activity of a country. In the attempt to capture more and better representative data of this activity, either the National Accounts data or the corresponding underlying system (the System of National Accounts - SNA), have been subject to successive improvements. Thus, National Accounts - Data and System (namely its nomenclatures) were considered in the specification of the contents of the SAM presented here, and were adopted as the base source of information.

In the SAM accounts representing the transactions within the economy there are production and institutional accounts. The former is divided into activity sectors (or industries), products and factors of production, which are worked together with the accounts of the institutional sectors of the latter. Thus, the representative transactions of the (primary) distribution of income are worked upon together with the redistribution and use of income, as well as capital and financial 
transactions. In this way, the network of linkages captured by the matrix format will allow for a better quantification of the multiplier effects in subsequent modelling.

In research using a SAM-based approach, the challenge is to find out what is the best use of the SAM, both in the numerical and the algebraic versions. Such research may support studies carried out in several areas, as well as the studies of those taking part in the policy decision process. This involves the best definition of the taxonomy of the SAM accounts and of the corresponding network of linkages.

In particular, when the focus of a study is on the role played by households (within the institutional sectors) in the socio-economic activity of a country during a pre-defined period (usually a year), all the data that can be studied by using the SAM can be further complemented with a Socio-Demographic Matrix (SDM).

Representing the households all the population of a country, the flows in its production (expressed in currency units), its consumption and also its income can be worked upon within a SAM framework. In turn, when the entire population of a country is studied within a SDM framework, its movements (expressed in numbers of human beings) can be represented in the form of a stock-flow matrix, which offers many possibilities for disaggregation. A SDM records the movements of the relationship between the opening and closing stock of a population for a particular period and also the flows of people during that period (births, deaths, immigration, emigration and changes between groups). Depending on the purpose of the study, active or passive sequences can be adopted to identify these groups. Usually the first step that is taken prior to the definition of these sequences is to identify the different age groups.

This paper reinforces the construction of numerical versions of SAMs from the SNA, and further study of possible algebraic versions of SAMs and SDMs is recommended in: Stone (1986, 1981 and 1973) and Santos (2014). 


\subsection{Constructing numerical versions of SAMs from the SNA}

The latest versions of the SNA have devoted a number of paragraphs to discussing the question of SAMs. The 2008 version mentions SAMs in Section D of Chapter 28, which is entitled "Input-output and other matrix-based analysis", in which a matrix is presented of the all the accounts in the SNA (ISWGNA, 2009, pp.519-522). This matrix is not, however, to be confused with the SAM that is presented below, although both practically cover all the flows recorded in the SNA accounts.

In turn, the European System of National and Regional Accounts in the European Union of 2010 (the adaptation for Europe of the 2008 version of the SNA - 2010 ESA) makes a reference to the SAM, stating that, amongst other features, it can be thought of as an expanded system of labour (satellite) accounts (EUPC, 2013, p.523).

The SAM that is presented below is a result of the research undertaken by the author within the above-mentioned methodological framework. Much effort was made to reconcile that framework with that which is defined by (the successive versions of) the SNA. Seeking to include as much as possible of the flows observed by the National Accounts, a version of the SAM is proposed which accompanied the application made for Portugal in 2011 - which was the base year of the adaptation to Europe of the above mentioned latest version of the SNA.

Accordingly, a square matrix is worked upon, in which the sum of the rows is equal to the corresponding sum of the columns. In keeping with what is conventionally accepted, and after some adjustments have been made to adapt this to the SNA, the following items are represented in the entries made in the rows: resources, incomes, receipts or changes in liabilities, and net worth; whilst the entries made in the columns are: uses, outlays, expenditures or changes in assets. Each flow is therefore recorded only once, in a cell of its own.

The starting point for the construction of a numerical SAM should be its design, i.e. the classification or taxonomy of its accounts. That taxonomy, together with the levels of adopted disaggregation, will both depend on the purposes for which the SAM is to be used, as well as on 
the way that the available information is organised. On the other hand, there needs to be a concern that the most significant features of economy-wide transactions will be represented, and that the SAM can also be used as the base for a model. A basic structure is proposed below, which adopts the National Accounts as the base source of information, takes into account the underlying SNA, and which also highlights the consistency of the whole system. The flexibility of that basic structure is shown, together with the possibilities that it presents for characterising problems and for achieving specific purposes. These can be seen as ways for going beyond the SNA, thus facing the dangers associated with the adoption of international standards and systems of classification and their failure to recognise important issues and realities.

\subsubsection{The SAM's basic structure and its consistency with the whole} system

Adopting the working method recommended by Stone, the basic structure for the SAM presented here is a summary set of the National Accounts and the controlling totals for the other levels of disaggregation, all of which will be analysed later. Thus, in keeping with the conventions and nomenclatures defined by the SNA, besides a rest of the world account, the proposed SAM also includes both production and institutional accounts.

Table 1 shows that basic structure, which represents the nominal transactions ("t") with which two indexes are associated. The location of these transactions within the matrix framework is described by those indexes, the first of which represents the row account, whilst the second represents the column account. Each cell of this matrix will be converted into a sub-matrix, with the number of rows and columns corresponding to the level of disaggregation of the row and column accounts. This same table also identifies blocks which are sub-matrices, or sets of sub-matrices with common characteristics. The specification of these blocks is made below and involves an identification of the flows of the National Accounts, which will continue to be the same, even if disaggregation is carried out to some degree - thereby preserving the consistency of the whole system. 
Table 1: The Basic SAM by blocks

\begin{tabular}{|c|c|c|c|c|c|c|c|c|}
\hline & $\mathrm{p}$ & $a$ & $\mathrm{f}$ & dic & dik & dif & $\mathrm{rw}$ & Total \\
\hline $\mathrm{p}-$ products & $\begin{array}{l}\text { TTM } \\
\left(t_{\mathrm{p}, \mathrm{p}}\right)\end{array}$ & $\begin{array}{c}\text { IC } \\
\left(t_{\mathrm{p}, a}\right)\end{array}$ & 0 & $\begin{array}{c}\mathrm{FC} \\
\left(\mathrm{t}_{\mathrm{p}, \mathrm{dic}}\right)\end{array}$ & $\begin{array}{c}\mathrm{GCF} \\
\left(\mathrm{t}_{\mathrm{p}, \mathrm{dik}}\right)\end{array}$ & 0 & $\begin{array}{c}\mathrm{EX} \\
\left(\mathrm{t}_{\mathrm{p}, \mathrm{rw}}\right)\end{array}$ & $\begin{array}{c}\mathrm{AD} \\
\left(\mathrm{t}_{\mathrm{p} .}\right)\end{array}$ \\
\hline $\begin{array}{l}a-\mathrm{a} \\
\text { ctivities }\end{array}$ & $\begin{array}{c}\mathrm{P} \\
\left(\mathrm{t}_{a, \mathrm{p}}\right)\end{array}$ & 0 & 0 & 0 & 0 & 0 & 0 & $\begin{array}{l}\mathrm{VPT} \\
\left(\mathrm{t}_{a} \cdot\right)\end{array}$ \\
\hline$f-$ factors & 0 & $\begin{array}{l}\mathrm{CFP} \\
\mathrm{GAV} \\
\left(\mathrm{t}_{\mathrm{f}, a}\right)\end{array}$ & 0 & 0 & 0 & 0 & $\begin{array}{c}\mathrm{CFP} \\
\left(\mathrm{t}_{\mathrm{f}, \mathrm{rw}}\right)\end{array}$ & $\begin{array}{l}\text { AFIR } \\
\left(t_{f} .\right)\end{array}$ \\
\hline $\begin{array}{l}\text { dic-(domestic) } \\
\text { institutions' } \\
\text { current account }\end{array}$ & $\begin{array}{c}\text { NTP } \\
\left(t_{\text {dic }, p}\right)\end{array}$ & $\begin{array}{c}\mathrm{NTA} \\
\left(\mathrm{t}_{\mathrm{dic}, a}\right)\end{array}$ & $\begin{array}{l}\text { CFP } \\
\text { GNI } \\
\left(t_{\text {dic, }, f}\right) \\
\end{array}$ & $\begin{array}{c}\mathrm{CT} \\
\left(\mathrm{t}_{\mathrm{dic}, \mathrm{dic}}\right)\end{array}$ & 0 & 0 & $\begin{array}{c}\mathrm{CT} \\
\left(\mathrm{t}_{\mathrm{dic}, \mathrm{rw}}\right)\end{array}$ & $\underset{\left(t_{\text {dic }}\right)}{A I}$ \\
\hline $\begin{array}{l}\text { dik-(domestic) } \\
\text { institutions' } \\
\text { capital account }\end{array}$ & 0 & 0 & 0 & $\begin{array}{c}\mathrm{S} \\
\left(\mathrm{t}_{\mathrm{dik}, \mathrm{dic}}\right)\end{array}$ & $\begin{array}{c}\mathrm{KT} \\
\left(\mathrm{t}_{\mathrm{dik}, \mathrm{dik}}\right)\end{array}$ & $\begin{array}{c}\mathrm{NLB} \\
\left(\mathrm{t}_{\mathrm{dik}, \mathrm{dif}}\right)\end{array}$ & $\begin{array}{c}\mathrm{KT} \\
\left(\mathrm{t}_{\mathrm{dik}, \mathrm{rw}}\right)\end{array}$ & $\begin{array}{l}\text { INVF } \\
\left(\mathrm{t}_{\mathrm{dik}} \cdot\right)\end{array}$ \\
\hline $\begin{array}{l}\text { dif - (domestic) } \\
\text { institutions' } \\
\text { financial account }\end{array}$ & 0 & 0 & 0 & 0 & 0 & $\begin{array}{c}\mathrm{FT} \\
\left(\mathrm{t}_{\mathrm{dif}, \mathrm{dif}}\right)\end{array}$ & $\begin{array}{c}\mathrm{FT} \\
\left(\mathrm{t}_{\mathrm{dif}, \mathrm{rw}}\right)\end{array}$ & $\begin{array}{l}\text { TFTR } \\
\left(t_{\text {dif }}\right)\end{array}$ \\
\hline $\begin{array}{l}\text { rw - rest of the } \\
\text { world }\end{array}$ & $\begin{array}{l}\text { IM\& } \\
\text { NTP } \\
\left(\mathrm{t}_{\mathrm{rw}, \mathrm{p}}\right)\end{array}$ & $\begin{array}{l}\text { NTA } \\
\left(\mathrm{t}_{\mathrm{rw}, a}\right)\end{array}$ & $\begin{array}{c}\mathrm{CFP} \\
\left(\mathrm{t}_{\mathrm{rw}, \mathrm{f}}\right)\end{array}$ & $\begin{array}{c}\mathrm{CT} \\
\left(\mathrm{t}_{\mathrm{rw}, \mathrm{dic}}\right)\end{array}$ & $\begin{array}{c}\mathrm{KT} \\
\left(\mathrm{t}_{\mathrm{rw}, \mathrm{dik}}\right)\end{array}$ & $\begin{array}{c}\mathrm{FT} \\
\left(\mathrm{t}_{\mathrm{rw}, \mathrm{dif}}\right)\end{array}$ & 0 & $\begin{array}{c}\text { TVRWP } \\
\left(\mathrm{t}_{\mathrm{rw}}\right)\end{array}$ \\
\hline Total & $\begin{array}{l}\text { AS } \\
\left(t_{\text {.p }}\right)\end{array}$ & $\begin{array}{l}\text { VCT } \\
(\mathrm{t} \cdot a)\end{array}$ & $\begin{array}{c}\text { AFIP } \\
\left(\mathrm{t}_{\mathrm{f}}\right)\end{array}$ & $\begin{array}{c}\text { AIP } \\
\left(t_{\text {dic }}\right)\end{array}$ & $\begin{array}{l}\text { AINV } \\
\left(t_{.}{ }_{d i k}\right)\end{array}$ & $\begin{array}{l}\text { TFTP } \\
\left(\mathrm{t}_{\text {dif }}\right)\end{array}$ & $\begin{array}{l}\text { TVRWR } \\
\left(\mathrm{t}_{\text {. } \mathrm{sw}}\right)\end{array}$ & \\
\hline
\end{tabular}

Source: Own construction.

Note: The first three accounts ( $\mathrm{p}=$ products (or goods and services), $a=$ activities (or industries) and $\mathrm{f}=$ factors (of production)) are the production accounts of the economy and the next three accounts ( dic $=$ current; dik $=$ capital; dif $=$ financial) are the accounts of the (domestic) institutions. The last account ( $\mathrm{rw}=$ rest of the world) represents the "external" part of the (domestic) economy.

A description of the blocks now follows (included in the texts are letters, followed by numbers between brackets, which are the flow codes of the National Accounts, in accordance with the 2008 SNA):

a) Production - P (cell: $\mathrm{t}_{a, \mathrm{p}}$; basic prices) - represents the output of goods and services (P1).

b) Domestic Trade is represented by the value of domestically transacted products, which can be either be domestically produced or imported.

B1) Intermediate Consumption - IC (cell: $\mathrm{t}_{\mathrm{p}, \mathrm{a}}$; purchasers' prices) - consists of the value of the goods and services consumed as inputs of the process of production, excluding those fixed assets whose consumption is recorded as consumption of fixed capital (P2).

b2) Final Consumption - FC (cell: $t_{p, d i c}$; purchasers' prices) - consists of the expenditure incurred by resident institutional units on goods or 
services which are used for the direct satisfaction of individual needs or wants, or the collective needs of members of the community (P3).

B3) Gross Capital Formation - GCF (cell: $t_{p, d i k}$; purchasers' prices) includes gross fixed capital formation, changes in inventories, and acquisitions less disposals of valuables (P5).

c) External Trade includes the transactions in goods and services from non-residents to residents, also known as imports (P7), or IM (cell: $\mathrm{t}_{\mathrm{rw}, \mathrm{p}}$; purchasers' prices), and the transactions in goods and services from residents to non-residents, also known as exports (P6), or EX (cell: $\mathrm{t}_{\mathrm{p}, \mathrm{rw}}$; purchasers' prices).

d) Trade and Transport Margins - TTM (cell: $t_{p, p}$ ) - amounts to zero and, when it is disaggregated and takes the form of a submatrix, it allocates the output of the trade and transport services used in the domestic trade to the supplied products.

e) Net taxes on production and imports

e1) Net Taxes on Production - NTA (cells: $\left.\mathrm{t}_{\mathrm{dic}, a} ; \mathrm{t}_{\mathrm{rw}, a}\right)$ - represents the (other) taxes on production (D29) minus the (other) subsidies to production (D39)

e2) Net Taxes on Products - NTP (cells: $\left.t_{d i c, p} ; t_{r w, p}\right)$ - represents the taxes on products (D21) minus the subsidies on products (D31).

f) Compensation of Factors of Production - CFP (cells: $\mathrm{t}_{\mathrm{f}, a} ; \mathrm{t}_{\mathrm{dic}, \mathrm{f}} ; \mathrm{t}_{\mathrm{f}, \mathrm{rw}} ; \mathrm{t}_{\mathrm{rw}, \mathrm{f}}$ ) - consists of the income of the institutional sectors originating from the compensation of employees (D1) and the compensation of employers and own-account (or self-employed) workers, as well as the compensation of capital, including property income (D4; B2g-B3g). Functional distribution is represented by the Gross Added Value - GAV (cell: $\mathrm{t}_{\mathrm{f}, a}$ ), whereas institutional distribution is represented by the Gross National Income - GNI (cell: $\left.t_{d i c, f}\right)$.

g) Current Transactions - CT (cells: $\left.t_{d i c, d i c} ; t_{d i c, r w} ; t_{r w, d i c}\right)-$ includes: current taxes on income, wealth, etc. (D5); net social contributions (D61); social benefits other than social transfers in kind (D62); other current transfers (D7), and; the adjustment made for the change in pension entitlements (D8). 
h) Capital Transactions - KT (cells: $\left.t_{d i k, d i k} ; t_{d i k, r w ;} t_{r w, d i k}\right)$ - includes: capital taxes (D91); investment grants (D92); and other capital transfers (D99).

i) Financial Transactions - FT (cells: $\left.t_{d i f, d i f} ; t_{d i f, r w} ; t_{r w, d i f}\right)$ - includes: monetary gold and special drawing rights (F1); currency and deposits (F2); debt securities (F3); loans (F4); equity and investment fund shares or units (F5); insurance, pension and standardised guarantee schemes (F6); financial derivatives and employee stock options (F7); and other accounts receivable/payable (F8).

j) Gross Saving - $S$ (cell: $\left.t_{d i k, d i c}\right)$ - measures the portion of aggregate income that is not used for final consumption expenditure and current transfers to domestic institutions or to the rest of the world (B8g).

k) Net Lending/Borrowing - NLB (cell: $t_{\text {dik,dif }}$ )

The net lending or borrowing of the total economy is the sum of the net lending or borrowing of the institutional sectors. It represents, respectively, the net resources that the total economy makes available to the rest of the world or the net resources that it receives from the rest of the world in order to finance the corresponding needs of investment funds (B9).

In this case, these amounts are recorded in the row(s) of the capital account, i.e. as changes in liabilities and net worth, and in the column(s) of the financial account, i.e. as changes in assets. This is why the mathematical signs of this item have been changed in relation to the SNA.

The construction of a SAM is easier when it is performed by blocks.

The totals of each account represent the corresponding sums of the cells in rows and in columns, with the following descriptions:

I. Products account ( $\mathrm{p})$ : Aggregate Demand - AD, the row sum (cell: $\mathrm{t}_{\mathrm{p}}$ ); Aggregate Supply - AS, the column sum (cell: t.p).

II. Activities account (a): Production Value - VPT, the row sum (cell: $\mathrm{t}_{a}$ ); Total Costs - VCT, the column sum (cell: t. $a$ ).

III. Factors of Production (f): Aggregate Factors Income (Received) - AFIR, the row sum (cell: $\mathrm{t}_{\mathrm{f}}$ ); Aggregate Factors Income (Paid) - AFIP, the column sum (cell: t.f). 
IV. Current account of (domestic) institutions (dic): Aggregate Income (received) - AI, the row sum (cell: $\mathrm{t}_{\text {dic. }}$ ); Aggregate Income (Paid) - AIP, the column sum (cell: $t_{\text {dic }}$ ).

V. Capital account of (domestic) institutions (dik): Investment Funds INVF, the row sum (cell: $t_{\text {dik. }}$ ); Aggregate Investment - AINV, the column sum (cell: t.dik).

VI. Financial account of (domestic) institutions (dif): Total Financial Transactions (Received) - TFTR, the row sum (cell: $t_{\text {dif. }}$ ); Total Financial Transactions (Paid) - TFTP, the column sum (cell: t.dif).

VII. Rest of the world account (rw): Value of Transactions to the Rest of the World (Paid) - TVRWP, the row sum (cell: $t_{\text {rw. }}$ ); Value of Transactions from the Rest of the World (Received) - TVRWR, the column sum (cell: t.rw).

From the above descriptions, two further advantages of the matrix presentation of the National Accounts can be highlighted: firstly, each transaction represents a single entry and can be characterised by its position and secondly; each account is represented by a row and a column, whose balance is ensured by the equality of their sums.

The Integrated Economic Accounts Table is a summary of all the detail observed by the SNA, including the full sequence of accounts for (domestic) institutional sectors, the rest of the world and the total economy. Based on this table, and taking into consideration the previous descriptions, it was possible to construct the basic SAM that is presented in Table 2, which represents the highest possible level of aggregation of the activity of Portugal as observed in the National Accounts of 2011 (at current prices).

Taking into consideration the description given of Table 1 above, and based on the reading of the products account for Portugal in 2011, which is represented in Table 2 - row and column $\mathrm{p}$, the main components of the aggregate demand and supply of goods and services transacted in the market and recorded by the Portuguese National Accounts can be identified in millions of Euros. Thus, reading in row, the total aggregate demand of 416,695 million Euros was composed of 172,577 million Euros of intermediate consumption, 150,944 million Euros of final consumption, 
32,764 million Euros of gross capital formation, and 60,410 million Euros of exports. Reading in column, the total aggregate supply of 416,695 million Euros (equal to the total aggregate demand) was composed of 326,819 million Euros of output of goods and services, 22,087 million Euros of net taxes on products received by the Portuguese Government, - 163 million Euros of net taxes on products sent to European Union institutions, and 67,952 million Euros of imports. A similar reading can be made for each of the other columns and rows of Table 2, for Portugal.

Therefore, as mentioned above, the basic SAM that has just been described can be considered to be the most aggregate summary set of the National Accounts, which represents a first level of the intended hierarchical method, with all the controlling totals for the next level of that hierarchy. Based on this, the consistency of the whole (supposedly) observed system can be ensured.

Table 2: Basic SAM of Portugal in 2011(Unit: $10^{6}$ euros)

\begin{tabular}{|l|c|c|c|c|c|c|c|c|}
\hline & $\mathrm{p}$ & $a$ & $\mathrm{f}$ & dic & dik & dif & rw & Total \\
\hline $\mathrm{p}-$ products & 0 & 172,577 & & 150,944 & 32,764 & & 60,410 & 416,695 \\
\hline$a$ - activities & 326,819 & & & & & & & 326,819 \\
\hline $\mathrm{f}-$ factors & & 154,848 & & & & & 8,048 & 162,895 \\
\hline $\begin{array}{l}\text { dic - (domestic) } \\
\text { institutions' } \\
\text { current account }\end{array}$ & 22,087 & 1,156 & 149,275 & 86,044 & & & 5,910 & 264,472 \\
\hline $\begin{array}{l}\text { dik - (domestic) } \\
\text { institutions } \\
\text { capital account }\end{array}$ & & & & 22,900 & 2,565 & 7,297 & 2,632 & 35,394 \\
\hline $\begin{array}{l}\text { dif - (domestic) } \\
\text { institutions } \\
\text { financial account }\end{array}$ & & & & & & 13,836 & $-7,397$ & 6,439 \\
\hline $\begin{array}{l}\text { rw - rest of the } \\
\text { world }\end{array}$ & $67,789^{(a)}$ & $-1,761$ & 13,620 & 4,584 & 65 & $-14,694$ & & 69,603 \\
\hline Total & 416,695 & 326,819 & 162,895 & 264,472 & 35,394 & 6,439 & 69,603 & \\
\hline
\end{tabular}

Sources: Statistics Portugal (INE); Portuguese Central Bank (Banco de Portugal).

(a) 67,952 (imports) less 163 (net taxes on products sent to the institutions of the European Union)

\subsubsection{Disaggregations and extensions}

As the National Accounts cover all the details covered by the basic structure presented above, some other levels of the above mentioned hierarchical method can be identified within the National Accounts, which 
provide other controlling totals for greater levels of disaggregation. As will be seen below, this disaggregation can be made at the levels of the production, institutional and rest of the world accounts, either within the scope of the SNA conventions, or not. The opposite applies to the case of aggregation. Therefore, it is possible to carry out a simpler aggregation and disaggregation of the accounts without losing the consistency of the system, in accordance with the specific requirements of the exercise carried out and the information available.

It is also worth mentioning that, although the quarterly National Accounts are not as complete as the annual ones, it would, nevertheless, be possible to carry out some further disaggregations from these accounts in terms of time. Furthermore, disaggregations can be made in terms of space, as regional accounts are also considered. In this case, it is possible to work with regions and countries, either individually, or as a group. It would even be possible to consider data in world terms, if the SNA could be adopted worldwide.

Extensions are also possible, either from the National Accounts, or from other sources of information, with a convenient adjustment to, or connection with, the whole system, in order to maintain consistency.

The 2008 SNA dedicates Chapter 29 to "Satellite accounts and other extensions", where the main idea is to serve specific analytical purposes, in a way that is consistent with the central framework, although not fully integrated into it. In this respect, the author would like to support the idea of Keuning and Ruijter (1988) of a "complete data set" which "could be tentatively labelled: a System of Socio-economic Accounts".

\section{i) Production accounts}

In the basic structure proposed above, production accounts are the accounts of products, activities and factors of production. These accounts correspond respectively to the SNA accounts of goods and services, production and the primary distribution of income. Thus, within these accounts, and depending on the available level of disaggregation, one can see how the available products are used, with some details being provided about the process of production and about the way in which 
the income resulting from that process is distributed among institutions and activities, as well as the ownership of assets.

The SNA uses the Central Product Classification (CPC) Version 2 (completed in December 2008) to classify products, which are organised into 10 sections, with the possibility of going as far as the fifth level of disaggregation within each of these.

In turn, the International Standard Industrial Classification of All Economic Activities (ISIC) Revision 4 (officially released in August 2008) is used to classify activities, which are organised into 23 sections, and their disaggregation is perfectly consonant with that of the product classification. The Supply and Use Table provides this information, usually at an intermediate level of disaggregation.

As described above, in the characterisation of the block representing the compensation of the factors of production, the disaggregation that can be made from the above-mentioned tables of the National Accounts is between labour (or the compensation of employees) and that which has been referred to as 'compensation of other factors', which includes the compensation of employers and own-account (or self-employed) workers and also the compensation of capital, namely property income. Such information can only be derived from the Integrated Economic Accounts Table if the products and activities accounts are not disaggregated. This can also be derived from the Supply and Use Table, if the same accounts are disaggregated.

As applied to Portugal, Table 3 presents the possible disaggregation of the factors of production accounts, based on the Integrated Economic Accounts Table, in which the products and activities accounts are not disaggregated.

\section{ii) Institutions and rest of the world accounts}

In the basic structure proposed above, domestic institutions are divided into current, capital and financial accounts. These accounts correspond, respectively, to the following SNA accounts: secondary distribution of income, redistribution of income in kind and use of income; capital, and; financial accounts. Within these accounts, depending on the level of dis- 
aggregation available, the current accounts show how national income is transformed into disposable income through the receipt and payment of current transfers, and how the latter is distributed between final consumption and saving. In turn, the capital account records the transactions linked to acquisitions of non-financial assets and capital transfers involving the redistribution of wealth, whereas the financial account records the transactions in financial assets and liabilities between institutional units, and between these and the rest of the world.

All the linkages between the domestic economy and the rest of the world (i.e. all the transactions between resident and non-resident units) are recorded in both the SAM and the SNA, through the rest of the world account.

Chapter 4 of the 2008 SNA specifies the institutional sectors, including the rest of the world, as well as their possible disaggregation, which in some cases can be taken as far as the third level, although normally it cannot be taken beyond the first level. In the case of the rest of the world, such disaggregation will certainly depend on the country, or group of countries, that adopt and adapt this system ${ }^{2}$.

At the first level of disaggregation, the accounts of both institutions and the rest of the world are part of the Integrated Economic Accounts Table. Higher levels of disaggregation, whenever these are possible, are usually published in the separate accounts of institutions. Even at the first level of disaggregation, any research carried out of the institutional sectors with transactions involving more than one row or column of the SAM, also requires the so-called "from whom to whom matrices". These matrices make it possible to fill in the cells of the sub-matrices of transactions taking place both within domestic institutions, and also between institutions and the rest of the world, which are recorded in the above-described blocks of current, capital, and financial transactions.

\footnotetext{
2 In the case of the 2010 ESA (Chapter 23), a second level of disaggregation is made, with a distinction being drawn between Member States and institutions and bodies of the European Union, and non-member countries and international organisations that are not resident in the European Union. For the former, disaggregation can be made as far as the fourth level.
} 
The disaggregation of specific institutional sectors makes it possible to analyse the most diverse aspects of the corresponding roles in the activity of countries. Santos (2007) is an example of a study of the role of government in general and its sub-sectors - central government, local government and social security funds.

The detailed study of the specific accounts of domestic institutions and their corresponding transactions also makes it possible to analyse specific aspects of the same activity, namely: the distribution and redistribution of income, using the current account; the redistribution of wealth, using the capital account; investment and its financing, and also the implicit levels of financing requirements and the availability of institutional sectors and the whole economy, using both the capital and financial accounts.

In turn, the rest of the world account can provide many possibilities for studying the international economic relations of the domestic economy.

Table 3 presents the possible disaggregation of the institutions' current and capital accounts, and it is derived from the Integrated Economic Accounts Table and the "from whom to whom matrices" for our application to Portugal. From that table, we can see a little more about the reality under study - Portugal in 2011. In the case of aggregate factors income - the so-called primary distribution of income, which amounts to 162,895 million Euros, it can now be seen that 82,006 million Euros represent the compensation of employees - row and column 3, and that 80,890 million Euros account for the compensation of other factors of production, namely employers and own-account workers, land and capital (including property income) - row and column 4.

Row 3 shows that the part of the gross-added-value generated in the domestic economy by residents and non-residents that is attributed to employee compensation, amounts to 81,617 million Euros, to which are added 388 million Euros generated abroad by residents. In turn, row 4 shows that the part of the gross-added-value generated in the domestic economy by residents and non-residents that is attributed to the above-mentioned other factors of production, amounts to 73,231 million Euros, to which are added 7,659 million Euros generated abroad by residents. 
Rows 3 and 4 enable the study of aspects related to the functional distribution of income.

Column 3 shows that the part of the gross national income generated in the domestic economy and abroad by residents which is attributed to compensation of employees and is received by households, amounts to 81,554 million Euros, to which are added 452 million Euros which are generated in the domestic economy by non-residents and sent abroad. In column 4, the part of the gross national income generated in the domestic economy and abroad by residents which is attributed to the compensation of other factors and is received by the various institutional sectors, amounts to 67,721 million Euros, to which are added 13,169 million Euros generated in the domestic economy by non-residents and sent abroad. From the cells of columns 3 and 4 , it is possible to study aspects related to the institutional distribution of income.

Just as the matrix form of the production accounts may be easily worked on from the supply and use tables, it would also be possible to work on the matrix form of the institutional accounts if some kind of "from whom to whom tables" were made official. This would be a crucial factor for implementing the SAM-based approach, in which SAMs with production and institutional accounts, that conveniently capture the circular flow of income and the underlying network of linkages, would form the basis for macroeconomic models which would be capable of reproducing the multiplier processes that are implicit in the socio-economic activity of countries. 
Table 3 SAM of Portugal in 2011, with disaggregated factors of production and the (domestic) institutions' current and capita accounts (Unit: $10^{6}$ Euros)

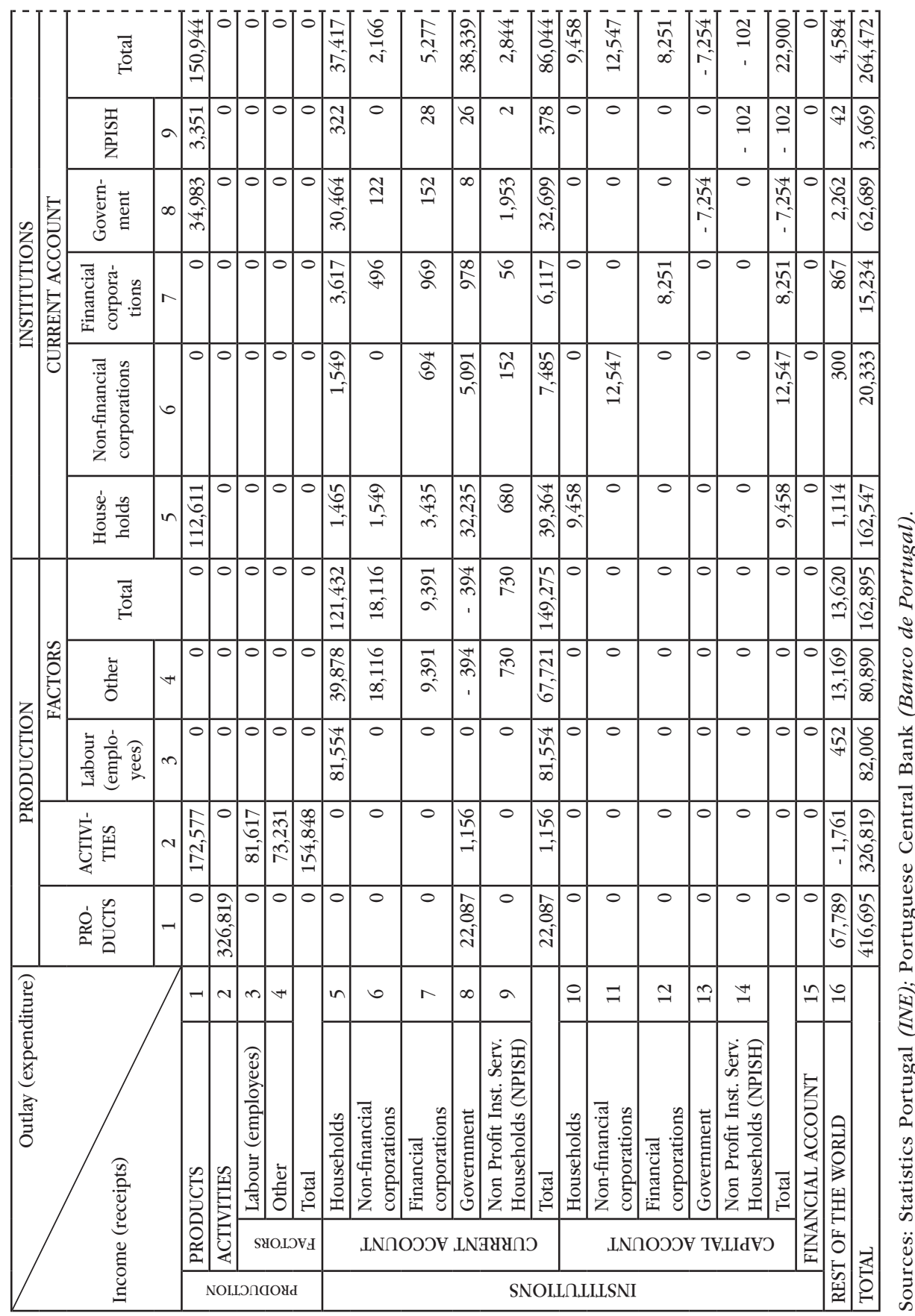


Table 3: (continued). SAM of Portugal in 2011, with disaggregated factors of production and the (domestic) institutions' current and capital accounts (Unit: $10^{6}$ Euros)

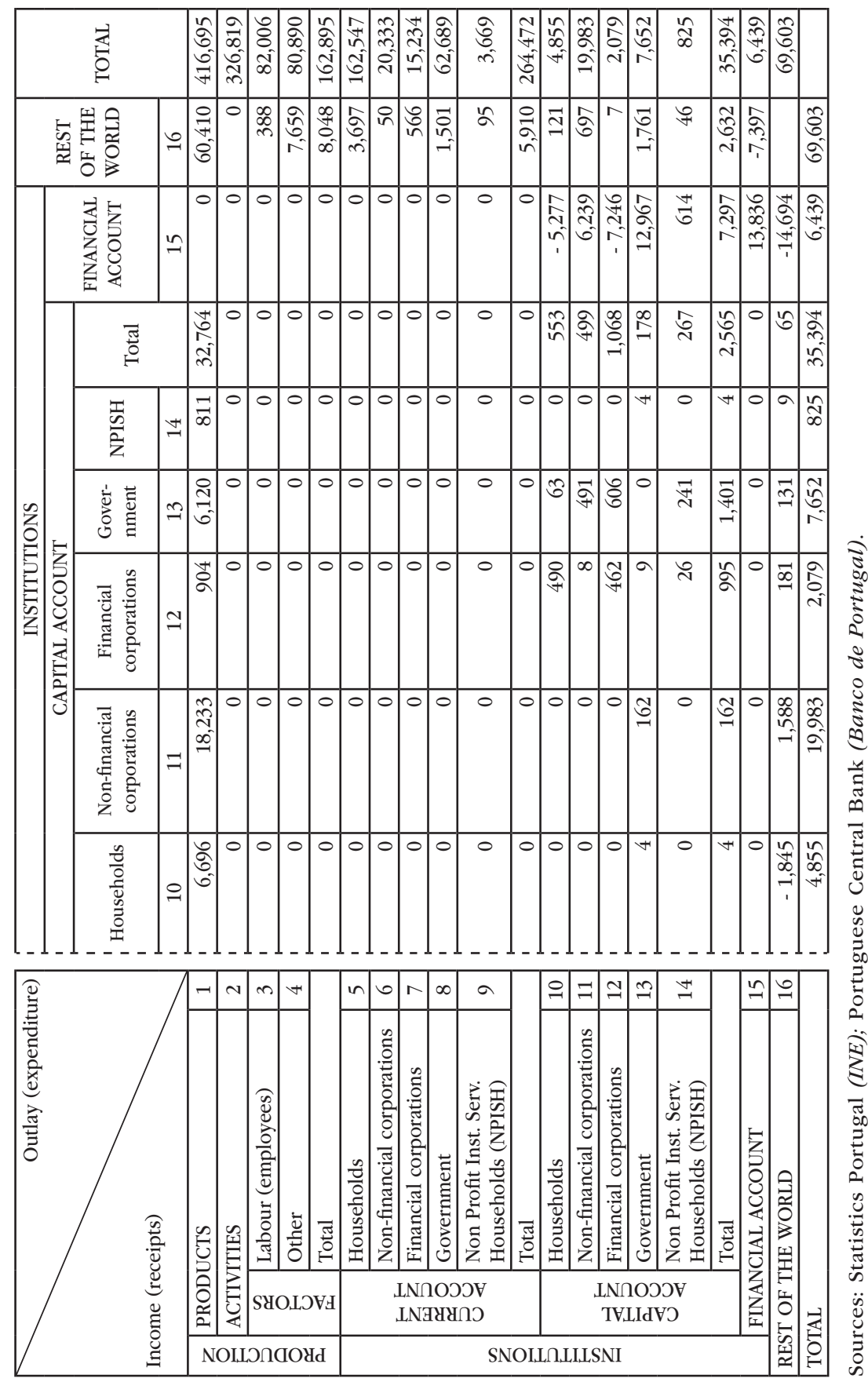




\subsubsection{Aggregates and balancing items}

As can be seen above, practically all the transactions of the National Accounts are covered by the SAM, and thus macroeconomic aggregates and balancing items can all be identified by it (see the description of the cells or blocks in Table 1, as well as Tables 2 and 3 for the application for Portugal).

Gross Domestic Product at market prices $\left(\mathrm{GDP}_{\mathrm{pm}}\right)$, which is usually considered to be the main macroeconomic aggregate, can be calculated using the following three known approaches:

- Production approach: $\mathrm{GDP}_{\mathrm{pm}}=\mathrm{P}-\mathrm{IC}+\mathrm{NTP}=\mathrm{t}_{\mathrm{a}, \mathrm{p}}-\mathrm{t}_{\mathrm{p}, \mathrm{a}}+\left(\mathrm{t}_{\mathrm{dic}, \mathrm{p}}+\right.$ (part of) $t_{r w, p}$ );

- Expenditure approach: $\mathrm{GDP}_{\mathrm{pm}}=\mathrm{FC}+\mathrm{GCF}+\mathrm{Ex}-\mathrm{IM}=\mathrm{t}_{\mathrm{p}, \mathrm{dic}}+\mathrm{t}_{\mathrm{p}, \mathrm{dik}}$ $+t_{p, r w}-($ part of $) t_{r w, p}$

- Income approach: GDP $\mathrm{pm}=\mathrm{GAV}+\mathrm{NTP}+\mathrm{NTA}=\mathrm{t}_{\mathrm{f}, \mathrm{a}}+\left(\mathrm{t}_{\mathrm{dic}, \mathrm{p}}+(\right.$ part of) $\left.t_{r w, p}\right)+\left(t_{d i c, a}+t_{r w, a}\right)$.

The Portuguese $\mathrm{GDP}_{\mathrm{pm}}$ in 2011 was 176,167 million Euros, which can be calculated from these three approaches as follows:

- Production approach: $\mathrm{GDP}_{\mathrm{pm}}=326,819-172,577+(22,087+(-163))$;

- Expenditure approach: $\mathrm{GDP}_{\mathrm{pm}}=150,944+32,764+60,410-67,952$;

- Income approach: $\mathrm{GDP}_{\mathrm{pm}}=154,848+(22,087+(-163))+(1,156+$ $(-1,761))$.

Domestic Product can be converted into National Product, by adding the compensation of factors received from the rest of the world, and by deducting the compensation of factors and the net indirect taxes (on both products and production) sent to the rest of the world, when these exist. Thus, from the cells described for the basic SAM, GDP $\mathrm{pm}_{\text {can }}$ be converted into Gross National Product at market prices $\left(\mathrm{GNP}_{\mathrm{pm}}\right)$, or Gross National Income $\left(\mathrm{GNI}_{\mathrm{pm}}\right)$, as follows: $\mathrm{GDP}_{\mathrm{pm}}+\mathrm{t}_{\mathrm{f}, \mathrm{rw}}-\mathrm{t}_{\mathrm{rw}, \mathrm{f}}-\mathrm{t}_{\mathrm{rw}, \mathrm{a}}-$ (part of) $t_{r w, p}$. On the other hand, as the SAM directly provides Gross National Income, this can also be calculated by simply adding the net indirect taxes (on both products and production) received by domestic institutions to the compensation of factors received by domestic institutions: $t_{d i c, f}+t_{d i c, p}+t_{d i c, a}$. The corresponding amount for Portugal in 2011 is 172,518 million Euros, for which the underlying calculations are as 
follows: $\mathrm{GNP}_{\mathrm{pm}}=176,167+13,620-8,048-(-1,761)-(-163) ; \mathrm{GNI}_{\mathrm{pm}}=$ $149,275+22,087+1,156$.

Disposable Income (Domestic or National) is very important and is calculated by adding the net current transactions received by domestic institutions to $\mathrm{GNI}_{\mathrm{pm}}: \mathrm{GNI}_{\mathrm{pm}}+\left((\right.$ received $\left.) \mathrm{t}_{\mathrm{dic}, \mathrm{dic}}+\mathrm{t}_{\mathrm{dic}, \mathrm{rw}}\right)-\left((\right.$ paid $) \mathrm{t}_{\mathrm{dic}, \mathrm{dic}}+$ $\left.t_{r w, d i c}\right)$. For Portugal this is: $172,518+(86,044+5,910)-(86,044+4,584)$ $=173,844$ million Euros.

In turn, gross aggregates can be converted into net aggregates (and balancing items) by deducting the consumption of fixed capital. This lies outside the basic SAM, but is part of the Integrated Economic Accounts.

Gross Saving (S) and Net Lending or Borrowing (NLB) are provided directly by the SAM, through $t_{\text {dik,dic }}$ and $t_{\text {dik,dif }}$, respectively, which, in the case of Portugal in 2011, are 22,900 and 7,297 million Euros respectively. As explained above, the latter amount represents Net Borrowing.

The main items for income and expenditure of the institutional sectors and of the rest of the world can be calculated from the respective rows and columns of the SAM. In the case of the institutional sectors: the total balancing item is the net lending/borrowing (NLB) of the respective institutional sector, with an opposite mathematical sign to that registered in the SAM; the current balancing item is the respective gross saving (S), and; the capital balancing item is the difference between the first and the second (NLB and S).

\subsection{An algebraic version of a SAM: the accounting multipliers}

The base methodology that is to be followed uses accounting multipliers, in keeping with the research of Pyatt and Roe (1977) and Pyatt and Round (1985).

Exogenous and endogenous accounts exist (see Table 4) and consequently the transactions in each cell of the SAM will be considered exogenous or endogenous, according to the corresponding row and column accounts.

From Table 4 , it can be written that

$$
\mathrm{y}_{\mathrm{n}}=\mathrm{n}+\mathrm{x}(1)
$$




$$
\mathrm{y}_{\mathrm{x}}=1+\mathrm{r}(2)
$$

The amount that the endogenous accounts receive is equal to the amount that they spend (row totals equal column totals). In other words, in aggregate terms, total injections from the exogenous into the endogenous accounts (i.e. the column sum of " $x$ ") are equal to total leakages from the endogenous into the exogenous accounts, i.e. considering $i$ ' to be the unitary vector (row), the column sum of " 1 " is:

$$
\mathrm{x} * \mathrm{i}^{\prime}=1 * \mathrm{i} \text {. }
$$

\begin{tabular}{|c|c|c|c|c|c|}
\hline & \multicolumn{2}{|c|}{ Endogenous } & \multicolumn{2}{|c|}{ Exogenous } & \multirow{2}{*}{ Total } \\
\hline & & $\Sigma$ & & $\Sigma$ & \\
\hline \begin{tabular}{|l|} 
Endogenous \\
\end{tabular} & $\mathrm{N}$ & $\mathrm{n}$ & $\mathrm{X}$ & $\mathrm{x}$ & $\mathrm{y}_{\mathrm{n}}$ \\
\hline Exogenous & $\mathrm{L}$ & 1 & $\mathrm{R}$ & $\mathrm{r}$ & $\mathrm{y}_{\mathrm{x}}$ \\
\hline Total & \multicolumn{2}{|c|}{$\mathrm{y}_{\mathrm{n}}$} & \multicolumn{2}{|c|}{$\mathrm{y}_{\mathrm{x}}^{\prime}$} & \\
\hline
\end{tabular}

Table 4: The SAM in endogenous and exogenous accounts

Source: Pyatt and Round (1985).

Note: As referred to above, rows represent resources, incomes, receipts or changes in liabilities and net worth. Columns represent uses, outlays, expenditures or changes in assets.

Key:

$\mathrm{N}=$ matrix of transactions between endogenous accounts; $\mathrm{n}=$ vector of the (corresponding) row sums.

$\mathrm{X}=$ matrix of transactions between exogenous and endogenous accounts (injections from first into second); $\mathrm{x}=$ vector of the (corresponding) row sums.

$\mathrm{L}=$ matrix of transactions between endogenous and exogenous accounts (leakages from first into second); 1 = vector of the (corresponding) row sums.

$\mathrm{R}=$ matrix of transactions between exogenous accounts; $r=$ vector of the (corresponding) row sums.

$\mathrm{y}_{\mathrm{n}}=\operatorname{vector}($ column$)$ of the receipts of the endogenous accounts ( $\hat{\mathrm{y}}_{\mathrm{n}}$ : diagonal; $\hat{y}_{n}{ }^{-1}$ : inverse); $y_{n}{ }^{\prime}=$ vector (row) of the expenditures of the same accounts.

$\mathrm{y}_{\mathrm{x}}=\operatorname{vector}($ column$)$ of the receipts of the exogenous accounts; $\mathrm{y}_{\mathrm{x}}{ }^{\prime}=$ vector (row) of the expenditures of the same accounts. 
In the structure of Table 4 , if the entries in the $\mathrm{N}$ matrix are divided by the corresponding total expenditures, a corresponding matrix (squared) can be defined of the average expenditure propensities of the endogenous accounts within the endogenous accounts or of the use of resources within those accounts. Calling this matrix $A_{n}$, it can be written that

$$
\begin{aligned}
& \mathbf{A}_{\mathrm{n}}=\mathrm{N} * \hat{\mathrm{y}}_{\mathrm{n}}{ }^{-1}(4) \\
& \mathrm{N}=\mathbf{A}_{\mathrm{n} *} \hat{\mathrm{y}}_{\mathrm{n}}(5)
\end{aligned}
$$

Considering equation (1), $\mathrm{y}_{\mathrm{n}}=\mathrm{A}_{\mathrm{n}} \mathrm{y}_{\mathrm{n}}+\mathrm{x}$ (6)

Therefore, $\mathrm{y}_{\mathrm{n}}=\left(\mathrm{I}-\mathrm{A}_{\mathrm{n}}\right)^{-1_{*}} \mathrm{x}=\mathrm{M}_{\mathrm{a}} * \mathrm{x} .(7)$

We thus have the equation which calculates the total receipts of the endogenous accounts $\left(y_{n}\right)$, by multiplying the injections " $x$ " by the matrix of the accounting multipliers:

$$
M_{a}=\left(I-A_{n}\right)^{-1} \text {. }
$$

On the other hand, if the entries in the $\mathrm{L}$ matrix are divided by the corresponding total expenditures, a corresponding matrix (non-squared) can be defined as the average expenditure propensities of the endogenous accounts into the exogenous accounts or as the use of resources from the endogenous accounts into the exogenous accounts. Calling this matrix $A_{1}$, it can be written that

$$
\begin{aligned}
& \mathrm{A}_{1}=\mathrm{L}_{*} \hat{\mathrm{y}}_{\mathrm{n}}{ }^{-1}(9) \\
& \mathrm{L}=\mathrm{A}_{1} * \hat{\mathrm{y}}_{\mathrm{n}}(10)
\end{aligned}
$$

Considering equation (2), $\mathrm{y}_{\mathrm{x}}=\mathrm{A}_{1 * \mathrm{y}_{\mathrm{n}}}+\mathrm{r}(11)$

Thus, $1=\mathrm{A}_{1} * \mathrm{y}_{\mathrm{n}}=\mathrm{A}_{1} *\left(\mathrm{I}-\mathrm{A}_{\mathrm{n}}\right)^{-1_{*}} \mathrm{x}=\mathrm{A}_{1} * \mathrm{M}_{\mathrm{a}} * \mathrm{X}$. (12)

Therefore, by using the accounting multipliers, the impact of changes in receipts is analysed at the moment when they occur, assuming that the structure of expenditure in the economy does not change. It is also assumed that excess capacity in the economy exists, as does production technology and resource endowment. 


\section{Identifying the structural features of a country's distribution and use of income with SAMs.}

Structural indicators for the functional and institutional distribution of generated income can be calculate from a SAM, as can indicators for the distribution and use of disposable income, which allows for an assessment of the distribution and use of a country's income.

In order to prepare the experiment performed in Section 4, the same methodology will be adopted, using Portugal in 2011 as an example, but now the year 2010 will also be added. From 2010 to 2011 there was an overall absolute decrease in all the aggregates mentioned below, except for savings.

The functional distribution of generated income is given by the distribution of gross added value - GAV - among the factors of production, through the structure of the sub-matrix in cell $\mathrm{t}_{\mathrm{f}, a}$ of the basic SAM (Table 1 ), with its level of detail depending on the disaggregation of the activities (column account) and also of the factors of production (row account). Table 5 shows the results for the application for Portugal, whereby, although with a decreased difference, more than half of the domestic income (income generated in Portugal by residents and non-residents alike) is compensation of employees, in 2010 (53.3\%) and 2011 (52.7\%).

Table 5: Portuguese functional distribution of income generated in 2010 and 2011 (in percentage terms)

\begin{tabular}{|l|r|r|}
\hline & 2010 & 2011 \\
\hline $\begin{array}{l}\text { Factors of Production } \\
\text { (generated income = gross added value or gross domestic product) }\end{array}$ & 53.3 & 52.7 \\
\hline $\begin{array}{l}\text { Labour } \\
\text { (employees) }\end{array}$ & 46.7 & 47.3 \\
\hline $\begin{array}{l}\text { Other } \\
\text { (employers and own-account workers; capital) }\end{array}$ & 100.0 & 100.0 \\
\hline \multicolumn{1}{|l|}{ Total } & & \\
\hline
\end{tabular}

Sources: Statistics Portugal (INE); Portuguese Central Bank (Banco de Portugal).

Note: Gross domestic product (at current prices) decreased 2.1\% from 2010 to 2011.

In turn, the institutional distribution of generated income is given by the distribution of gross national income - GNI, through the structure 
of the submatrix in cell $\mathrm{t}_{\mathrm{dic}, \mathrm{f}}$ of the basic SAM (Table 1). In this case, the level of detail will depend on the disaggregation of the factors of production (column account), and of the current account of the domestic institutions (row account). Table 6 shows the results of our application, with households being the most significant, but with a decreased share of the national income (income generated in Portugal by residents and non-residents alike), from $83.6 \%$ in 2010 , to $81.3 \%$ in 2011 . On the contrary, non-financial and especially financial corporations have reinforced positions, which is the opposite to that of general government.

Table 6: Portuguese institutional distribution of income generated in 2010 and 2011 (in percentage terms)

\begin{tabular}{|l|r|r|r|r|r|}
\hline \multirow{2}{*}{} & \multicolumn{4}{|c|}{ Factors of Production } \\
\cline { 2 - 6 } & \multicolumn{1}{|c|}{$\begin{array}{c}\text { Labour } \\
\text { (employees) }\end{array}$} & $\begin{array}{c}\text { Other } \\
\text { (employers and own-account } \\
\text { workers; capital) }\end{array}$ & \multicolumn{3}{c|}{ Total } \\
\hline & $2010=2011$ & 2010 & 2011 & 2010 & 2011 \\
\hline Institutions (generated income = gross national income) & \multicolumn{2}{|c|}{8} \\
\hline Households & 100.0 & 62.6 & 58.9 & 83.6 & 81.3 \\
\hline Non-financial corporations & & 26.7 & 26.8 & 11.7 & 12.1 \\
\hline Financial corporations & & 7.5 & 13.9 & 3.3 & 6.3 \\
\hline General government & & 2.2 & -0.6 & 0.9 & -0.3 \\
\hline $\begin{array}{l}\text { Non-profit institutions } \\
\text { serving households }\end{array}$ & & 1.1 & 1.1 & 0.5 & 0.5 \\
\hline \multicolumn{1}{|c|}{ Total } & 100.0 & 100.0 & 100.0 & 100.0 & 100.0 \\
\hline
\end{tabular}

Sources: Statistics Portugal (INE); Portuguese Central Bank (Banco de Portugal).

Note: Total gross national income (at current prices) decreased $0.7 \%$ from 2010 to 2011 $(3.9 \%$ in the case of the households).

As described in Subsection 2.2.3, the disposable income of the institutional sectors can be calculated in the same way for the whole economy. Thus, each institutional sector obtains its disposable income by excluding from the corresponding gross national income, current transfers paid to other institutional sectors and to the rest of the world, and by including current transfers received from other institutional sectors and the rest of the world. In the case of the government, the net taxes on production and imports are also included. Disposable income is then used in final consumption and savings, except in the case of non-financial and financial corporations, which do not have any final consumption. As can be seen 
in Table 7, households have more than half of the disposable income of Portugal, although this share has decreased from $72.9 \%$ in 2010 , to $70.2 \%$ in 2011 . The same trend occurs in the case of non-financial corporations, whose disposable income, overall, is $7.3 \%$ in 2010 , and $7.2 \%$ in 2011. The remaining institutional sectors have increased shares, with the emphasis being on financial corporations, whose share of the total disposable income are $2.2 \%$ in 2010, and $4.7 \%$ in 2011.

Furthermore, the share of total disposable income spent in final consumption decreased from $89 \%$ in 2010 , to $86.8 \%$ in 2011 . By sacrificing savings, households increased the share of their lower absolute disposable income spent on final consumption (from $90.3 \%$ in 2010 , to $92.3 \%$ in 2011). With negative savings, general government and the non-profit institutions serving households exceed their corresponding disposable incomes with final consumption, although with a decreased share.

Table 7: Portuguese distribution and use of disposable income among institutions in 2010 and 2011 (in percentage terms)

\begin{tabular}{|c|c|c|c|c|c|c|}
\hline & \multirow{2}{*}{\multicolumn{2}{|c|}{$\begin{array}{c}\text { Distribution of } \\
\text { Disposable Income }\end{array}$}} & \multicolumn{4}{|c|}{ Use of Disposable Income } \\
\hline & & & \multicolumn{2}{|c|}{$\begin{array}{l}\text { Final Consumption } \\
\text { Expenditure }\end{array}$} & \multicolumn{2}{|c|}{ Saving } \\
\hline & 2010 & 2011 & 2010 & 2011 & 2010 & 2011 \\
\hline Households & 72.9 & 70.2 & 90.3 & 92.3 & 9.7 & 7.7 \\
\hline Non-financial corporations & 7.3 & 7.2 & --- & --- & 100.0 & 100.0 \\
\hline Financial corporations & 2.2 & 4.7 & -- & --- & 100.0 & 100.0 \\
\hline General government & 15.9 & 16.0 & 133.9 & 126.2 & -33.9 & -26.2 \\
\hline $\begin{array}{l}\text { Non-profit institutions } \\
\text { serving households }\end{array}$ & 1.6 & 1.9 & 113.9 & 103.1 & -13.9 & -3.1 \\
\hline Total & 100.0 & 100.0 & 89.0 & 86.8 & 11.0 & 13.2 \\
\hline
\end{tabular}

Sources: Statistics Portugal (INE); Portuguese Central Bank (Banco de Portugal).

Note: Total gross disposable income (at current prices) decreased 0.5\% from 2010 to 2011 ( $4.2 \%$ in the case of the households).

From the above analysis it can be concluded that, between 2010 and 2011, Portugal experienced a general absolute decrease in domestic, national and disposable income. A change in the structure of the distribution and use of income can also be observed. A smaller share of income is allocated to households, whilst financial corporations nearly doubled their share in the case of national income, and in the case of 
disposable income, this more than doubled. The share of savings of total disposable income increased, to the detriment of the final consumption of the general government and non-profit institutions serving households, as households spent a larger share of their (smaller) disposable income in final consumption.

\section{Experimenting a change in a country's income with a SAM-based approach.}

Let us now study the changes described in the previous section, using the methodology described in Section 2. Taking an overall view of the content of that section, a general conclusion can be drawn - although possible, in the view of the author, this task is neither easy, nor quick. In fact, so many flows of income are involved and there are so many intervening factors, that a thorough explanation would exceed the limits of time and space of this chapter. Instead, we identify some of the many potentialities of SAMs.

Considering the importance of the households' institutional sector, which represent the total population in a country, as already mentioned, and using our application to Portugal, the following example will show a possible SAM-based approach, considering the taxes on income and wealth, paid by the households to the government.

In 2011, the Portuguese general government received 10,554.04 million Euros of taxes on income and wealth from households, which was 932.295 million Euros more than in 2010. From 2010 to 2011, income generated by the Portuguese households decreased $4.2 \%$, and the percentage of that income that was paid to the Portuguese government in taxes on income and wealth increase from $7.6 \%$ in 2010 , to $8.7 \%$ in 2011 . Table 8 shows the relative importance of those amounts with regards the aggregate income of those institutional sectors, that is, in the row/column sum of the current accounts of each.

Our experiment will calculate the macroeconomic effects of the above mentioned increase of 932.295 million Euros in the taxes on income and wealth paid by the households to the government. 
Table 8. Relative importance of taxes on income and wealth paid by the households to the general government in the corresponding aggregate incomes.

\begin{tabular}{|l|c|c|}
\hline & 2010 & 2011 \\
\hline Households & $5,7 \%$ & $6,5 \%$ \\
\hline Government & $15,4 \%$ & $16,8 \%$ \\
\hline
\end{tabular}

Source: Statistics Portugal (INE).

Thus, from a SAM of Portugal in 2010, which is the equivalent to Table 3, and considering the methodology described in Subsection 2.3 and the purpose of working with a flow from the households to the government, the (current and capital) accounts of the households were set as exogenous, as also were the financial and the rest of the world accounts. The accounting multipliers were next calculated and run, after having increased the cell $(8,5)$ of current transfers from the households to the government, in the amount that corresponds to the increase registered for taxes on income and wealth paid by the households to the government from 2010 to 2011 (932.295 million Euros). From the replied SAM $\left(2010^{\text {after } \Delta}\right)$, the (new) macroeconomic aggregates were calculated, as explained is Subsection 2.2.3. Table 9 shows the percentage changes in these aggregates and final consumption and gross savings: between 2011 and 2010; before (2010), and; after the mentioned change $\left(2010^{\mathrm{after}} \Delta\right)$, both for the total economy and for the two institutional sectors involved in the experiment - households and the government.

Table 9: Percentage changes in macroeconomic aggregates, final consumption and gross saving in Portugal from 2010 to 2011.

\begin{tabular}{|l|c|c|c|c|c|c|}
\hline \multirow{2}{*}{} & \multicolumn{2}{|c|}{ Total Economy } & \multicolumn{2}{c|}{ Households } & \multicolumn{2}{c|}{ Government } \\
\cline { 2 - 7 } & $2011-10$ & $2011-10^{\text {after }}$ & $2011-10$ & $2011-10^{\text {after }}$ & $2011-10$ & $2011-10^{\text {after }}$ \\
\hline GDP & -2.1 & 2.3 & --- & --- & -- & -- \\
\hline GNI & -0.7 & 0.9 & -3.9 & 4.3 & -4.5 & 4.9 \\
\hline GDI & -0.5 & 0.7 & -4.2 & 4.2 & -0.4 & 2.0 \\
\hline FC & -3.0 & 3.5 & -2.1 & 2.2 & -6.1 & 8.2 \\
\hline S & 19.3 & -16.7 & -23.3 & 30.3 & -23.1 & 32.1 \\
\hline
\end{tabular}

Source: Own construction. 
Key:

GDP $=$ Gross Domestic Product Gross Domestic Product at market prices.

GNI = Gross National Income.

GDI $=$ Gross Disposable Income.

$\mathrm{FC}=$ Final Consumption.

$\mathrm{S}=$ Gross Saving.

Thus, the columns "2011-10" show the effects of the total changes that occurred from 2010 to 2011, and in columns "2011-10after $\Delta$ " show the effects of the change in the taxes on income and wealth paid by the households to the government, ceteris paribus (that is, if everything else remained constant). Comparing these two effects, for both the total economy and for households or the government, a negative mathematical sign can generally be associated with the former, and a positive mathematical sign can generally be associated with the latter. Therefore, as the change in the taxes on income and wealth paid by the households to the government is part of the total changes, some contribution to contradict the general trend can be attributed to the experimented change. It can also be said that at a first glance, a change which worsens the financial conditions of households, also has impacts at other levels, and on the economy as a whole, which, in the end, improves the general situation. We reached a similar conclusion to that of a similar experiment that was performed for the years 1995 and 2005 (Santos, 2010). Much more could have been studied and, certainly concluded, if we had had access to information by groups of households.

Whilst recognising the limitations of the adopted algebraic version (another could have been adopted in this same experiment), the features of the presented SAM and a SAM-based approach allowed the above described experiment and the corresponding results highlighted the emphasis of specific aspects, from which an assessment of the macroeconomic effects of a change in the income of households and government was made.

This research is just an illustration of how much could be derived from the described methodology, and even from the results of its use. 


\section{Concluding remarks}

By using the form of a square matrix, with rows and columns representing production, institutions and rest of the world accounts, a Social Accounting Matrix (SAM) can represent all the transactions within a domestic economy and also those between a domestic economy and the rest of the world.

By adopting the National Accounts - Data and System - as the base source of information, that "economy" is identified within a country, whose socio-economic activity is studied, using the SAM as a working tool. By capturing the circular flow of income and the underlying network of linkages, the SAM enables the structural features of both production and income distribution to be analysed together, providing the basis for macroeconomic models which are capable of reproducing the multiplier processes, implicit in the socio-economic activity of countries. Thus, in a SAM-based approach, this activity can be measured and modelled, depending, respectively, on whether the SAM is in a numerical or in an algebraic version.

Apart from presenting the specificities of this methodology, an empirical study was carried out, using an application for Portugal. Having identified distribution of income as being one of the various areas of the socio-economic activity of a country, which can be researched using the above-mentioned tool, some aspects of the reality under study (Portugal in 2010 and 2011) were highlighted, and an experiment was carried out which simulated an intervention in its functioning.

Numerical versions of SAMs of Portugal in 2010 and 2011 were constructed using the National Accounts, which permitted the calculation of structural indicators, from which the functional and institutional distribution of generated income and the distribution and use of disposable income could be identified. In the case of the functional distribution of (domestic) income, although this represented the major share, it was possible to identify a decrease in the importance of labour (employees) with regard to capital, and employers and own-account workers. In the case of the institutional distribution of (national) income, as well as that 
of disposable income, households saw their greater shares reduced in favour of other institutions, especially financial corporations. In turn, the largest share of disposable income used in final consumption was reduced, to the detriment of savings.

From numerical versions of SAMs of Portugal in 2010 and 2011, it was also possible to identify a general (nominal) decrease in the underlying macroeconomic (gross) aggregates of: domestic product, national income, disposable income.

The accounting multipliers, which were calculated from the SAM of Portugal in 2010, allowed an experiment to be carried out which simulated a change in taxes on income and wealth paid by the households to the government, which was equal to the actual increase registered for that amount from 2010 to 2011. Having calculated a new numerical version of the SAM, the macroeconomic effects of that change then permitted the identification of a general increase of the above-mentioned macroeconomic aggregates. Thus, as the change used in the above-mentioned experiment was a part of the total change that occurred from 2010 to 2011, some of the contribution that contradicted the latter can be attributed to the former. Another possible conclusion that can be drawn from the results of this experiment is that, by reproducing the multiplier processes, our working tool showed that a change which, at a first glance, worsens the financial situation of households, also has an impact at other levels, and on the economy as a whole, which, ultimately, improves the overall situation.

Much more research can be carried out using SAM-based approach methodology, especially at the level of SAM-based models, or of SAM algebraic versions, and such research will certainly continue to be carried out.

Acknowledgements: The author gratefully acknowledges the financial support from national funds provided by FCT (Fundação para a Ciência e a Tecnologia) Portugal for the research and writing of this chapter, which forms part of the Strategic Project: UID/ECO/00436/2013. 


\section{References}

EUPC - European Union Parliament and Council, European System of National and Regional Accounts in the European Union, EU Regulation No. 549/2013, Official Journal of the European Union, L174, Volume 56, 26 June 2013.

ISWGNA - Inter-Secretariat Working Group on National Accounts (United Nations, European Commission, International Monetary Fund, Organisation for Economic Cooperation and Development and World Bank), System of National Accounts 2008, Series F, No. 2, Rev. 5, United Nations, New York, 2009.

KEUNING S. and RUIJTER W., "Guidelines to the construction of a Social Accounting Matrix", Review of Income and Wealth, 34, 1988, pp.71-100.

PYATT, G. and ROE, A. Social Accounting for Development Planning with special reference to Sri Lanka, Cambridge: Cambridge University Press, 1977.

PYATT, G. and ROUND, J., "Accounting and Fixed Price Multipliers in a Social Accounting Matrix Framework", in G. Pyatt, and J. Round, (coord.), Social Accounting Matrices. A Basis for Planning, A World Bank Symposium, World Bank, pp. 52-69, 1985.

SANTOS, S., "Approach to the socio- economic activity of countries with a Social Accounting Matrices supported by Socio-Demographic Matrices. An application to Portugal",. Working Paper Series - SSRN (Social Science Research Network) abstract=2530735, 2014.

SANTOS, S., "A QUANTITATIVE APPROACH TO THE EFFECTS OF SOCIAL POLICY MEASURES. AN APPLICATION TO PORTUGAL, USING SOCIAL ACCOUNTING MATRICES”. EERI (ECONOMICS AND ECONOMETRICS RESEARCH INSTITUTE) RP (RESEARCH PAPERS) 2010/33; MPRA (MUNich PERSONAl RePEC ARChiVE) PAPER NO. 23676, 2010.

SANTOS, S., "Modelling Economic Circuit Flows in a Social Accounting Matrix Framework. An Application to Portugal". Applied Economics, 39, 2007, pp. 1753-1771.

STONE, R., "Demographic Input-Output: An Extension of Social Accounting", in: I. Sohn (coord), Readings in Input-Output Analysis: Theory and Applications, Oxford University Press, USA, 1986, pp.151-172.

STONE, R., Aspects of Economic and Social Modelling, Editions Droz, Genève (Suisse), 1981.

STONE, R., "A System of Social Matrices", Review of Income and Wealth, 19, 1973, pp.143166. 
Série Investigação

Imprensa da Universidade de Coimbra

Coimbra University Press

2015

mais

Programa Operacional Regional do Centro

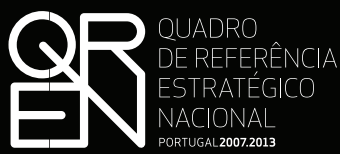

PORTUGAL 2007.2013

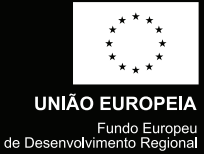

- $\mathbf{U}$

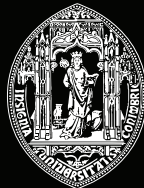

C •

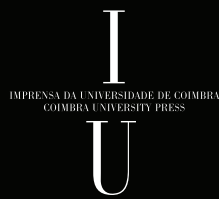

